\title{
Transatlantica
}

Revue d'études américaines. American Studies Journal

$2 \mid 2011$

Sport et société / Animals and the American

Imagination

\section{Baseball and American Foreign Policy}

\section{Robert Elias}

\section{(2) OpenEdition}

Journals

Édition électronique

URL : https://journals.openedition.org/transatlantica/5478

DOI : $10.4000 /$ transatlantica.5478

ISSN : 1765-2766

Éditeur

Association française d'Etudes Américaines (AFEA)

Référence électronique

Robert Elias, "Baseball and American Foreign Policy », Transatlantica [En ligne], 2 | 2011, mis en ligne le 10 juin 2012, consulté le 01 février 2023. URL : http://journals.openedition.org/transatlantica/5478 ; DOI : https://doi.org/10.4000/transatlantica.5478

Ce document a été généré automatiquement le 1 février 2023

\section{(c) $($ ) $(9)$}

Creative Commons - Attribution - Pas d'Utilisation Commerciale - Pas de Modification 4.0 International - CC BY-NC-ND 4.0

https://creativecommons.org/licenses/by-nc-nd/4.0/ 


\title{
Baseball and American Foreign Policy
}

\author{
Robert Elias
}

1 While many have observed baseball's longstanding resonance with U.S. domestic life, our national pastime has also figured prominently in how America has projected itself abroad-in its foreign, military, diplomatic and globalization policies. And vice versa: U.S. foreign policy has affected baseball, as well.

2 For more than two centuries, baseball has shown up in surprising ways as America has emerged in the world, and then built itself into an empire. While baseball was played in America as far back as the Revolutionary War, it was first designated the "national pastime" in the 1850s. Since then, the sport has worked hard to maintain that status. To do so, baseball-and especially major league baseball (MLB) - has tried to associate itself with the values of the American dream. It has also sought to equate itself with American masculinity and patriotism, and with U.S. military endeavors, in particular, especially the nation's wars and interventions.

\section{The National Pastime Tradeoff}

3 In America's efforts to expand its frontiers, it soon looked overseas. Baseball was enlisted in America's imperial quests and it helped colonize other lands, from the Caribbean to Asia to the Pacific. The game was regularly part of U.S. "civilizing missions" launched abroad, either militarily or economically, and sometimes bolstered by the forces of "muscular Christianity." Baseball was used to sell and export the American way. It took its place in the globalization of the world, even if Americanization was more so the objective. In America's foreign diplomacy, baseball was often regarded as the nation's "moral equivalent of war." And at home, baseball was used to promote patriotism and nationalism.

4 Affiliating itself with true blue Americanism has had its benefits, but perhaps some negative repercussions as well. Routinely, patriotism has been conceptualized not as support for the nation's ideals, but rather as loyalty to official policies. In exchange for 
its good standing as the national pastime, has baseball trapped itself into a blind adherence to U.S. foreign and military policies? Baseball has long engaged in a "national pastime tradeoff," whereby it must religiously toe the official government or military line, in return for being able to maintain its claim as the national game. At stake is far more than a symbolic designation; substantial owner profits are potentially on the line, as well as the sport's independence. Likewise, baseball has parroted America's approach to globalization in its own business dealings abroad. And, as MLB has become its own empire, some wonder whether it any longer represents the game's best interests.

5 With more Americans, in the last three decades, identifying football as their favorite sport, can baseball still sustain its claim as the national game? To beat back the challenge, must baseball re-double its flag-waving patriotism or instead pursue a new role in American society? What can we learn, for example, from baseball's recent response to the September 11 attacks and to America's get-tough military policies, including the wars on terrorism, Afghanistan, and Iraq-which some view, ironically, as U.S. foreign policy on steroids? Should baseball remain wedded to the U.S. empire or can it convey a different America to the world?

\section{Major Characters and Questions}

6 To understand the present, we must revisit the past. What, exactly, has been baseball's relationship to American foreign and military policies? It's a baseball history that reveals a colorful, and often startling, cast of characters. It involves generals, from Washington to MacArthur to Eisenhower to Powell, and presidents from Lincoln to Nixon to Bush to the Roosevelts. It's the story of foreign leaders, such as Sun Yat Sen, the Emperor Hirohito, the King of England, and Hugo Chavez, and politicians, from Jesse Helms and Rudy Giuliani to J. Edgar Hoover and Madeleine Albright. The game has preoccupied writers from Mark Twain and Walt Whitman to Sir Arthur Conan Doyle and Tom Clancy, and featured entertainers such as Jimmy Stewart, Jose Feliciano, and Tim Robbins, industrialists such as Henry Ford, and media moguls such as Hearst, Turner and Murdoch. And it's a baseball history that involves dozens of ballplayers, managers and executives in endlessly unexpected ways.

7 Examining baseball's historic relationship with America's foreign policy establishment raises a long list of provocative questions. Why was a military general chosen as baseball's "founder"? What interrupted the Seventh Cavalry's regular series of baseball games in the Black Hills? Why were baseball games played in Egypt at the foot of the Great Sphinx? What baseball executive was nearly court-martialed for kidnapping the Kaiser Wilhelm? Which ballplayer was proposed as a peacemaker between the U.S. and Japan? What role did the game play in the World War II Japanese-American concentration camps? Which second-string big league catcher was really an American spy? Which Negro Leaguers played baseball at gunpoint for a Dominican dictator? How did the Mexican Revolution threaten MLB? Could the Washington Senators have signed Fidel Castro before the Cuban Revolution and changed the course of history? Why did a major leaguer refuse to stand for the singing of God Bless America?

8 And most important: in the early twenty-first century, is baseball the sport of America's bright future? Or-perhaps reflecting the nation that created it-is baseball an empire that's destined to strike out? I explore these questions in my forthcoming 
book, The Empire Strikes Out: How Baseball Sold U.S. Foreign Policy and Promoted the American Way Abroad.

In this essay, we'll examine a few of those questions. We'll do so by reviewing some of the greatest hits of American foreign policy, which we'll reconsider from a unique perspective: through the lens of baseball. Historically, we'll see baseball's relationship to U.S. wars, interventions and resistance; to America's militarization and patriotism, and Cold Wars; and to U.S. espionage, diplomacy, and globalization. This then will provide a foundation for examining contemporary America: that is, what is the relationship between baseball's steroids controversy and U.S. foreign and military policies in the post-9/11 world?

\section{America's Wars}

The United States has a long history of wars, and baseball has been involved in every one of them. Forms of baseball were played during the Revolutionary War, including at Valley Forge; even George Washington played. The sport was also played during the War of 1812, including games Americans played in British prisoner-of-war camps. And in the Mexican War of the 1840s, while Henry David Thoreau sat in jail protesting the U.S. invasion of Mexico and Abraham Lincoln opposed it in Congress, some American soldiers were playing baseball south of the border.

11 Abraham Lincoln played baseball and attended games even during the Civil War, where the sport was played informally and in organized contests as the main entertainment for soldiers, in their own camps and in prisoner-of-war camps. Baseball was spread extensively by the War, especially as soldiers returned home to the North, South and West in the late 1860s. Most U.S. soldiers in the Indian Wars played baseball as their primary recreation. Led by General George Custer, the Seventh Cavalry played organized games around the nation, and bats and balls were carried around with the soldiers few other supplies. Among those who perished at the Little Bighorn in 1876 was the Seventh Cavalry's baseball team.

The sinking of the U.S.S. Maine in Havana, Cuba in 1898 was used as the pretext for launching the Spanish American War and the subsequent Philippine War. The death of the ship's baseball team was a rallying point for revenge, and baseball was employed to "civilize" and "control" the liberated Cubans, Filipinos and Puerto Ricans. While U.S. entrance into World War I in 1917 was supposed to "make the world safe for democracy," organized baseball wanted to "make the world safe for baseball," and thus it went to war, hoping to spread the game to Europe, and engaging in rousing nationalistic displays at home, such as ballplayers holding close-order military drills at ballparks, wielding their bats as if they were rifles.

In World War II, ballplayers were a "highly visible aspect of the military war machine" and became "symbols for their fellow Americans to follow." This allowed major league games to continue through the early 1940s, and it solidified baseball's claim as the national pastime. Baseball rallied to support the Korean War in 1950 as well, including prominent ballplayers such as Ted Williams and Jerry Coleman. Baseball was even used as a cover and distraction for the surprise attack the U.S. launched from Japan on Inchon, which drove back the North Korean forces. 
By the time of the Vietnam War in the late 1960s, MLB finally, after many tries, got a military general as its Commissioner, which also ensured baseball's support for yet another U.S. war. Against the Vietnam War, however, some ballplayer dissent arose, but it was swiftly marginalized. Baseball was involved in the surrogate wars launched by the Reagan administration in the Caribbean and Central America during the 1980s. Remarkably, some viewed baseball in Nicaragua and Cuba as evidence of Soviet subversion. And while limiting its commitment abroad, baseball was also the foremost cheerleader for America's Gulf War attack in the early 1990s, helping the U.S. overcome the "Vietnam syndrome" with jingoistic displays at home. Among other things, U.S. troops played baseball in Israel during that War.

\section{Interventions and Resistance}

In America's 230 years, the U.S. military has intervened in other nations more than 200 times, about once a year throughout American history. Baseball has routinely tagged along, for its own promotion and as a distraction and social control during U.S. occupations. It's produced a mixed picture of domination and resistance.

Baseball followed the flag soon after the Civil War, and joined America's earliest interventions, often in Latin America. By the beginning of the twentieth century, Teddy Roosevelt was among those leading the forces of American expansion abroad. Roosevelt claimed the U.S. should "speak softly but carry a big stick." Sometimes the stick was a baseball bat. When the bat wasn't a metaphor for military force, it was instead used to help pacify local populations during interventions and occupations.

After World War II, MLB was outraged at Jorge Pasquel's 1946 raids of U.S. ballplayers for the Mexican League, which threatened to create a diplomatic incident between the U.S. and Mexico. Yet Pasquel viewed it as payback not only for the Latinos MLB was stealing away, but also for the repeated U.S. military interventions in Mexico over the years, including a bombing attack on Pasquel's home town of Vera Cruz in 1914.

When President Richard Nixon sent American troops, which helped the U.S.-installed Nicaraguan tyrant, Anastasio Somoza, loot the international aid arriving for the 1972 Managua earthquake, baseball star Roberto Clemente was outraged. He insisted on delivering his Puerto Rican aid personally. He died, trying, in a plane crash-arguably a casualty of longstanding U.S. foreign policy support for repressive dictators.

\section{Militarization and Patriotism}

19 Baseball has also played a prominent role in war training, preparation, and enlistments. It has promoted nationalism and patriotism, and closely associated itself with American militarism-even in the story baseball invented about its own creation. The myth that Abner Doubleday invented baseball was concocted by baseball entrepreneur Albert Spalding to establish baseball as purely American, to help overcome America's inferiority complex with Britain, and mostly to associate baseball with a military hero: Doubleday had fought valiantly in the Mexican, Indian and Civil Wars.

Baseball was repeatedly enlisted not only for morale but for military training, such as during World War I, when baseball's "batting eye" was attributed with promoting a 
soldier's "shooting eye," and when baseball playing was used to train soldiers to throw grenades, under the motto: "That Arm, Your Country Needs It." The War Department adopted the slogan: "every American Soldier a baseball player." President Woodrow Wilson advocated the Star Spangled Banner as the national anthem and as a rallying point for getting the U.S. into World War I. Baseball obliged, playing it at more and more ballgames, including every World Series since 1918. When Congress finally officially approved the war song (featuring "bombs bursting in air") as the official anthem in 1931, baseball was given the most credit for its adoption.

During World War II, in German prison camps, baseball was used to bolster American morale and even to hatch escape plans. Back in the U.S., the DiMaggio family was instrumental in canceling plans to send Italian Americans to U.S. prisoner-of-war camps, and Kenichi Zenimura led the effort in Japanese American detention camps to use baseball to survive the encampment ordeal and prove Japanese American patriotism and loyalty.

\section{Cold Wars}

Baseball played a central role in combating the "Red Menace," prior to World War II, and in anti-communist crusades during the Cold War. Since the 1920s, for example, the American Legion has been fighting the "Red Menace" and promoting military patriotism. Its Junior Baseball Program has been in the forefront of its anti-communist crusade, and as a major supplier of baseball talent, MLB has conformed closely to the Legion's militarism, and definitions of patriotism.

Since World War II, Little League, Inc. has advocated quasi-military values of God, country and loyalty among children and their parents. Both at home and abroad, it has "promoted Americanism against the godless ideology of communism." Recently, George W. Bush and David Petraeus became the first Little League graduates to become U.S. President and U.S. Supreme Commander, respectively. And only a couple of years ago, Secretary of State Condoleezza Rice was promoting Little League as a foreign policy initiative in Chile and elsewhere in Latin America.

After surviving his ordeal of breaking the color barrier in MLB, Jackie Robinson was viewed as a "model" African American. As such, however, he was pressured into testifying in 1949 before the notorious House UnAmerican Activities Committee to rebut the claim made by the black communist, Paul Robeson, that African Americans would never fight as soldiers to defend the racist United States against the Soviet Union. Robinson later characterized this contribution to Cold War anti-communism as "the greatest regret of my life."

In the 1950s and 1960s, Commissioner Ford Frick committed MLB to the Cold War anticommunist crusade. And in the U.S. press, baseball was used, for example, to condemn Soviet leader Joseph Stalin for starting trouble in Korea and other nations. In America, so tainted was the color "red" that the Cincinnati Reds changed their name to the Redlegs in the 1950s. When they eventually changed it back, the Cincinnati GM said: "We were Reds before they were," in reference to the team's 1882 founding date.

In retrospect, U.S. Senator Eugene McCarthy observed that: "Among the early finds by Washington Senators scouts [in Cuba was a] prospect named Fidel Castro. He was turned down because he didn't have a major league fast ball. But an aspiring pitching 
ace spurned can be a dangerous man with a long memory." Not merely Cuba, but also Cuban baseball, have been major objects of contention in the Cold War since the early 1960s.

\section{Espionage}

Baseball has even been involved in U.S. spying, espionage, and covert operations abroad. Right after World War I, for example, Larry MacPhail-future baseball innovator and major league general manager-led a kidnapping attempt in Holland against the Kaiser Wilhelm, violating Dutch neutrality and triggering a diplomatic crisis, while nevertheless generating much applause from the U.S. military. Was this a case of American unilateralism in the face of the norms of international diplomacy? Where have we seen that recently?

An obscure American named Moe Berg infiltrated Latin American governments during World War II, conducted espionage against the German atomic bomb program, and was assigned to assassinate the German scientist, Werner Heisenberg. He was a genius who spoke twelve languages, practiced law, and had degrees from Princeton, Columbia, and the Sorbonne, yet he spent fifteen years playing major league baseball, which served as a cover for his real profession: Berg was an American spy.

What were Moe Berg's credentials for his European spying, and for receiving the U.S. Medal of Honor and CIA tributes? When he was a ballplayer, he joined several MLB tours of Japan in the 1930s, where he conversed in Japanese, spied on the government, and filmed Japanese shipyards, industrial and military sites, and downtown Tokyo for the U.S. Office of Strategic Services. Supplementing other intelligence, Berg's film was credited for the success of the bombing raid U.S. Lieutenant Colonel Jimmy Doolittle led over Japan in 1942 in retaliation for the Pearl Harbor attack.

\section{Diplomacy}

The sport has been used for U.S. foreign policy objectives, and organized baseball has long viewed itself and the game as a vehicle of peacekeeping and diplomacy. It's had both successes and failures along the way. Before World War II, for example, both the U.S. and MLB believed hostilities with Japan could be avoided through the sport the two nations shared. And as a national hero in Japan, through his many visits, Babe Ruth was viewed as a special ambassador. Yet, baseball diplomacy failed when Japan attacked Pearl Harbor; indeed, Japan used baseball for aggression not peace, not dissimilar to how the sport had been used elsewhere by the U.S.

31 Although Babe Ruth had been revered in Japan, in World War II Japanese soldiers sought to insult the U.S. by yelling: "To Hell with Babe Ruth!" or even "Fuck Babe Ruth" when fighting the Americans. Even so, if Ruth couldn't prevent the war, then could he perhaps help end it? The State Department proposed that Ruth fly to Guam to broadcast a translated radio message urging the Japanese to surrender. But the plan was scrapped, and a few days later, Truman ordered the bombs dropped on Hiroshima and Nagasaki.

When the post-World War II Japanese recovery began to wilt, General MacArthur called in ballplayer and manager Lefty O'Doul and the San Francisco Seals to boost morale and 
forestall communism. O'Doul was an overwhelmingly popular ambassador, and using baseball, he drew huge crowds and a new enthusiasm for the rebuilding effort, for which he was toasted by MacArthur and the Japanese Emperor, and inducted into the Japanese Baseball Hall of Fame.

After decades of Cold War conflicts between the U.S. and Cuba (including U.S.-induced defections from Cuba's national baseball team), Peter Angelos and the Baltimore Orioles proposed baseball diplomacy with Fidel Castro and Cuba in the late 1990s. While initially opposed by the State Department, a baseball series was held, nevertheless, in Baltimore and Havana, generating hopes for a more permanent thaw in relations.

\section{Globalization}

Organized baseball was among the earliest U.S. institutions to pursue globalization. More recently, baseball has rejuvenated and dramatically stepped up its globalization efforts, in line with other leading U.S. corporations. Baseball's claim as the national pastime has meant not only support for mainstream U.S. domestic and foreign politics; it has also reflected the spirit of capitalism. As early as the 1880 s, prominent businessmen-most notably former ballplayer and baseball executive Albert Spaldingbegan pushing baseball as a marketable and profitable commodity, and for this he was counted among the Robber Barons of the late nineteenth century.

In 1888, Spalding launched a World Baseball Tour, which took the game and major leaguers to Europe, Hawaii, New Zealand, Australia, Ceylon, and also Egypt-where the ballplayers tried to climb the Great Sphinx and then held a game there, much to the horror of the locals. The mission was an early example of globalization-to build Spalding's business empire. By the early twentieth century, his sporting goods outlets were found in dozens of American and foreign cities-and the Spalding Company still thrives today. The World Tour was a model for other U.S. corporations going abroad.

36 A century later, in the 1990s, the Clinton administration was promoting U.S. globalization, the World Trade Organization, and new markets in the Far East and elsewhere, courting nations such as China, despite its dismal human rights record. Baseball cartoons (such as one saying about China: "Well, no, he doesn't exactly know the rules, but he can hit!") were used to help sell Clinton's global policies. MLB was leading the way in its own industry. As baseball commissioner Bud Selig noted: "It's a global economy."

While the U.S. and MLB had been invading Latin America and the Caribbean for decades, a rejuvenated intervention was provoked by globalization's quest for cheap labor. Latino and Asian workers were targeted to man the wave of new American factories abroad. Likewise, MLB tapped cheap Haitian and Costa Rican laborers to make its baseballs and other equipment, and it harvested Latin ballplayers for only a fraction of what U.S. ballplayers were being paid-often exploiting Latin children in the process. As one scout admitted: "There is no difference between General Motors and the Houston Astros. One product is to be sold, and the other is to be used in the major leagues. It's just like making Cadillacs."

Baseball has been used by U.S. corporations abroad to sell their products and maintain their operations amidst foreign populations. But as a major corporation itself, MLB has also sold itself overseas. The latest strategy is the World Baseball Classic, which allows 
MLB to expand the game, tap new markets, and audition the world's best players, all while keeping total control over the sport. Who needs the Olympics?

\section{Baseball and Heavy Artillery}

If these, then, are a sampling of baseball's historic intersections with American foreign and military policy, then what have been the sport's more recent encounters? As we know, in the last decade MLB has confronted one challenge above all else: the scandal wrought by performance-enhancing drugs. While seemingly an internal problem, the steroids crisis might also be seen as a metaphor for America's role in the world after the fall of the Berlin Wall, and especially after the 9/11 terrorist attacks. And beyond metaphor, baseball's role in America's response to those attacks took a dramatic and tangible form. To trace these developments, we must examine not only baseball's experience with steroids but also its much longer history of performance enhancement.

Nearly a century ago, as the 1920 s began, the U.S. was suffering a loss of innocence from the recently concluded World War I, and from the Black Sox World Series scandal. It sought rejuvenation and new vistas after the closing of the American frontier. The emerging ballplayer, Babe Ruth, was admired not merely for being a star, and not merely for the way his phenomenal home runs were revolutionizing the game. Ruth represented "power," and his home runs (rather than Commissioner Landis's sanctions) not only transformed and saved baseball (after the cheating scandal); they also seared themselves into the national consciousness, "invoking epic journeys of Homer in the Odyssey and the Iliad." "Heavy artillery" had won the recent war, and the "big hitters" were now winning in baseball and in America's endeavors, both at home and abroad. It wouldn't be the last time the U.S. and baseball were looking for a boost.

\section{Baseball on Steroids}

41 Ever since Ruth captured the U.S. imagination with his prodigious slugging, the home run has mirrored the American psyche. Its rise in importance paralleled America's rise as a world power. Arguably, the U.S. has been addicted to that power ever since. It has characterized both America's foreign policy and America's national sport. Occasionally, however, there's been a power deficit, such as the aftermath of the Vietnam War fiasco. There have been similar lulls in baseball.

It may not be surprising, therefore, that if America's military power broke out of its shackles in the 1990s and overcame the "Vietnam Syndrome" with the Gulf War and other interventions, then baseball would find a way to reassert its power and overcome the scandal and disillusionment caused by the 1994 baseball strike and World Series cancellation. This came not from Commissioner Selig (despite being its main cheerleader), but rather from Babe Ruth's successors, Mark McGwire and Sammy Sosa. So compelling was their 1998 home run race that it generated tens of thousands of new fans, and became the talk of America. For awhile, rivalries seemed to recede in favor of national community. McGwire's repeated references to the American dream and Sosa's calls for a new Dominican-American dream left misleading but nevertheless profound messages about American greatness and strength. 
Most of all, Americans were awed by the power McGwire and Sosa generated with each mighty shot. Hitting more home runs, harder and longer, held a visceral appeal. Even sexual politics got involved. Signs at ballparks all over the country read: "Chicks Dig the Long Ball." And as Richard Ben Cramer has noted: in Babe Ruth's time, as well as in more recent times, Americans "love power. It's about how we see ourselves. It's how we're 'good' when we're very good-with overwhelming force." Reinvigorated, baseball seemed stronger than ever. Of course, it begged the question: where did all that newfound power actually come from? MLB didn't want to know and even though it did know, it certainly didn't want to tell.

There was abundant evidence, however, that steroids were being widely used during the 1990s. Desperate to rescue the game from disillusioned fans, however, MLB looked the other way. The home run barrage saved the game, but eventually the chickens would come home to roost. Widely reviled, but nevertheless prophetic, Jose Canseco first blew the whistle on his own steroid use and that of his fellow players. When it took him only three years to break McGwire's new home run record, Barry Bonds then became the lightning rod for the steroids scandal.

Along the way, there were steroids admissions and denials. After being traded to the Yankees, the contrite Jason Giambi was put on trial by the ravenous New York media. Former San Diego Padres star, Ken Caminiti, admitted he had used steroids when he won the National League Most Valuable Player Award in 1996. In contrast, the Texas Rangers and Baltimore Orioles star, Rafael Palmeiro, joined McGwire and Sosa in testimony before Congress in denying he used steroids. Despite his reassurances, Palmeiro later tested positive for steroids and was driven from the game. ${ }^{1}$

More recently, the Mitchell Report compiled a list of at least one hundred other ballplayers who used steroids. And Roger Clemens was accused by his trainer of using performance enhancers-a significant development not only because of his superstar status, but also because it posed the possibility that pitchers and not merely hitters were using steroids. Clemens also appeared before Congress, to deny steroid use, but nobody believed a word he said. And of course the very latest steroids "bad boys" are Alex Rodriguez and Manny Ramirez. It all made one wonder whether such drug use wasn't completely pervasive in the sport.

\section{Long History of Performance Enhancers}

Yet while the focus today is on steroids, drugs are not new to the national pastime. In 1866, Washington ballplayers were using opium to enhance their play, and before World War I, cocaine, heroin, marijuana and even natural steroids use was not uncommon. The first ballplayer widely known for using a performance enhancer was the pitcher Jim "Pud" Galvin, a Hall of Famer who won more than 300 games. Galvin used an elixir of Brown-Sequard, which was testosterone drained from the gonads of some animal. Using tonics like this was widespread and not discouraged. Later, Babe Ruth used the same thing, this time extracted from sheep testes.

8 Through the early 1900s, Coca Cola was widely used by players as a "pick-me-up," no doubt because it still contained cocaine. According to a 1902 ad, Coca Cola was "invigorating when one is in training. A few bottles on the bench will quiet the nerves when the game is close." Star hitter and Hall of Famer, Nap Lajoie, is shown, claiming

Transatlantica, 2 | 2011 
he had been drinking Coca Cola to help his game for years and would continue, so that he could "be in the game for several years yet to come." Coca Cola was also endorsed by the star pitcher Rube Waddell, who claimed the drink was "stimulating to body and mind, and had pulled him through many tight games..." That is, these players were enjoying liquid cocaine whenever they needed a boost.

Others ballplayers claimed they were helped more by beer, as reflected in a popular pre-1900 saying: "Pure elixir of malt and hops beats all the drugs and all the drops." A leading beer advocate was Mickey Welch, another 300 game winner and Hall of Famer. This was music to the ears of the beer barons, who were among the primary owners of major league baseball teams for many decades. Ruth wasn't shy of alcohol either, and Mickey Mantle claimed he did some of his best hitting with a hangover. Some even argued that tobacco, especially snuff tobacco, improved their games. Since the 1950s, amphetamines or "greenies" have been rampant in team clubhouses, and considered essential for getting through the season.

For awhile, marijuana use was also common, and the star pitcher Bill Lee was fined for admitting he sprinkled pot on his buckwheat pancakes each morning. Several years later, Lee was asked what he thought about mandatory drug testing for ballplayers and he said: "Well, I've tested just about all of them, but I'm not sure I'd want to make it mandatory." This, of course, is not what the Commissioner had in mind.

\section{U.S. Foreign Policy on Steroids}

51 In sum, performance enhancers such as steroids are not new, but what do steroids in baseball have to do with U.S. foreign policy? We can answer this by taking a closer look at the events immediately leading up to 9/11 and then its aftermath. Both baseball and America entered the twenty-first century brimming with confidence. Newly elected president George W. Bush claimed that not only the last century but also the next century would be the "American century," too. Flush with baseball's rebound via its late 1990s home run power surge, Commissioner Selig likewise saw good things to come for the game. Yet they might have underestimated the perils and fragility of both empires.

Thus, the U.S. was not prepared when terrorists struck on September 11, 2001. In the months leading up to $9 / 11$, only three years after Mark McGwire set the new singleseason record of 70 home runs, Barry Bonds was on pace to break it again. A consistent home run hitter, some nevertheless wondered about Bonds' power burst, noting his expanding bulk compared to his earlier playing days. But after the terrorists struck and America sought to get back on track, the Bonds' home run quest was a welcome distraction. It was too exciting to worry how he got there. But if Bonds was "juiced" on his way to setting a new record of 73 home runs, then it only foreshadowed an America "on juice" as well-an emerging U.S. foreign policy on steroids.

Before 9/11, it was difficult to envision baseball as a symbol around which a leader could rally the American people in times of crisis such as Franklin Roosevelt [did] during the Great Depression and World War II. Nevertheless, Commissioner Bud Selig and assorted politicians-from Rudy Giuliani to George W. Bush-would try. After the terrorist attacks, Selig ordered all baseball games postponed. Yet he also invoked Roosevelt's "green light" for baseball, claiming the sport was too central to the national fabric to stop the games completely. Instead, MLB embraced the flag and led the call to 
"support the troops." Having the games soon proceed indicated, symbolically, that America was functioning and would be fighting back.

Baseball served as a "shelter during the storm, [bearing] much of the burden for healing the nation after September 11." Each game "became a kind of village green where people could talk and deal with their fears." When the games resumed, they supplied the primary stage for stirring displays of patriotic unity. When he was given the start in the first Philadelphia Phillies game after the attacks, Robert Person said: "I am pitching for the whole nation." Arizona Diamondbacks pitcher Curt Schilling led baseball with his outspoken endorsement of President Bush, his military response to 9/11, and his eventual re-election.

Virtually every major league ballpark was awash with patriotic gestures. Moments of silence were religiously observed, and patriotic music punctuated games. Fields and stands were blanketed with red, white and blue. Silent auctions were held and benefit games were played for the Red Cross. Players wore caps honoring New York's police, firefighters and emergency crews, and visited shelters and fire houses. Fans held candles, prayed and sang, and chanted "USA! USA!" Yankee Stadium held a memorial service, Mets players raised money for the Twin Towers Relief Fund, and Diamondback players visited "ground zero."

The terrorist attacks immediately politicized baseball. President Bush "used baseball as a major patriotic statement" at the World Series and elsewhere. Maverick Media, the President's image maker, later repackaged footage from Bush's baseball appearances, playing them repeatedly during his reelection campaign.

\section{Air Strike from the Pitcher's Mound}

Broadcast by the conservative Fox Network, the 2001 World Series' games were framed by images of U.S. flags and tanks and the national anthem's almost non-stop performance. Pitting the Yankees and the Diamondbacks, the Series was scripted as "nationalist patriotism in support of U.S. military action." When the Series moved to New York for game 3, President Bush prepared to throw out the first pitch. When he saw where Bush was practicing, Yankees shortstop Derek Jeter told him: "This is New York. If you throw like that from the base of the mound, they're going to boo you." Taking Jeter's advice, Bush walked to the top of the mound, threw a perfect strike and then heard the roar of "USA! USA!" He later reported the pitch as the highlight of his presidency.

Political pundit Chris Matthews claimed this showed Bush's military and leadership prowess: "some things you can't fake. Either you can throw a strike from sixty feet or you can't. This is about knowing what to do at the moment you have to do it-and then doing it," presumably with a little help from your friends. Surely this proved our President would lead us out of our national nightmare. Sportswriter Bill Littlefield claimed he didn't mind having politicians showing up at ballgames, where they "are less likely to engage in dangerous mischief. Nobody has ever called an air strike from the pitcher's mound," he said, "the proximity of military jets notwithstanding." But President Bush's World Series appearance was tantamount to just that.

59 At the game was a torn American flag, retrieved from ground zero and flown over Yankee Stadium. In the outfield, fans cheered a reenactment of New York City 
firefighters raising another flag over the World Trade Center debris, duplicating World War II's Iwo Jima. As such, "the game of baseball was narrated by an image that endorsed the moral justness of war, [promoting] the conclusion that military retaliation was the only appropriate response." It undermined any script that might have allowed fans to debate the subject.

Baseball's central role in pulling New York and the nation out of the 9/11 catastrophe and in priming the country for war, could not be denied. As captured in the film Nine Innings at Ground Zero, so profound was the connection that even the widely hated Yankees were suddenly transformed into America's team. While Arizona's World Series victory ruined the Yankees' fairy tale ending, the military response the games had helped legitimize, emerged full force. President Bush announced the War on Terrorism and the impending attack on Afghanistan. Thus did America quickly squander the national community and international good will the attacks had initially engendered, and like a nation on performance-enhancing drugs, the U.S. lashed out with wave after wave of massive violence.

\section{Baseball's Afghanistan and Iraq Wars}

61 Patriotism reigned at Opening Day in April 2002 and the military hoopla only further escalated. "Whether it is 1942 or 2002," it was observed, "baseball and U.S. military history will always blend together." While the McGwire-Sosa home run race of the late 1990s brought in new fans, still more were generated by 9/11. According to Dan Wachtell: "baseball went on, because if we stop playing, the Taliban Terrorists win. During the off season, Taliban management saw their major league roster decimated and their minor league systems put out of business. During spring training, missiles rained upon their outfield and now the Taliban is picked to finish in last place and is in serious danger of being contracted." An overly optimistic assessment of the War, but even so, baseball could apparently help fight the terrorists.

Reminiscent of past American military occupations, baseball was introduced by U.S. soldiers to Afghanis (and especially children) when the U.S. launched the Afghanistan war in 2002. Some wondered whether baseball wasn't again being used to distract and pacify the local population. In any case, Afghan children began playing baseball. A U.S. Special Forces Little League was also formed. As in past U.S. wars and occupations, American soldiers also played baseball, and did their best to follow their home teams when posted abroad. Even better were the visits by ballplayers to war zones, which MLB had been sponsoring as far back as World War I. Anaheim Angels outfielder, Tim Salmon's visit to the Bagram Air Base in Afghanistan was one of many ballplayer tours.

In 2002, in his "Axis of Evil" speech, President Bush added Iraq to Iran and North Korea as nations fostering terrorism and weapons of mass destruction. Then, at 9:11 p.m. on September 11, 2002, MLB paused to commemorate the previous year's terrorist attack. Commissioner Selig gave a moving tribute. ESPN broadcast 12 continuous hours of baseball. Yankee Stadium dedicated a new monument. In a letter read at every major league game, President Bush observed that: "During the past year baseball helped bring Americans together [...] and promoted the healing process." A few days later, Bush hosted members of the Texas Rangers, the club he previously owned-and the team, by the way, that produced at least $20 \%$ of the ballplayers the Mitchell Report listed as 
having tested positive for steroids. Then Bush met with top lawmakers to plan his next battle: the war on Iraq.

One of the biggest cheerleaders for the War was Roger Clemens, who addressed military battalions during a mobilization farewell in March 2003. After the attack and occupation, baseball was brought to Iraq as entertainment for U.S. soldiers and for "good will" and "social control" purposes for the Iraqi people. Teams of Iraqi boys were put together and outfitted by the U.S. army, which also formed its own company baseball teams. But despite appearances, not all was well with baseball's relationship to America's invasion and war in Iraq.

\section{The Hall of Fame Protects the Troops}

At home, attention turned unexpectedly to the Cooperstown Hall of Fame. While the baseball shrine had never avoided patriotic displays, such as having the American flag as the backdrop for its logo, it usually kept a low profile. In 1999, however, Dale Petroskey became the Hall's new president and especially since 9/11 he had become a visible cheerleader for the Republican Party and U.S. military policies. Then in 2003, Petroskey cancelled the 25th anniversary celebration of the landmark baseball film Bull Durham, because two of its stars Tim Robbins and Susan Sarandon were outspoken Iraq War critics.

Petroskey began militarizing the Hall of Fame early on. Imposing a boot camp atmosphere, strict military-style dress and grooming codes were imposed for Hall employees. Free admission was offered to all active and retired military, and a large, permanent podium to honor Hall of Famers who were military veterans was unveiled in a 2002 Memorial Day ceremony. Special plates were also inserted under the individual plaques of every Hall of Famer who served in the military. Some wondered whether they were visiting the Baseball Hall of Fame or rather the U.S. Military Hall of Fame.

In canceling the Bull Durham event, Petroskey wrote Robbins and Sarandon that: "your public criticism of President Bush at this sensitive time helps undermine the U.S. position, which puts our troops in even more danger. As an institution, we stand behind our President and our troops in this conflict." All but calling them traitors, Petroskey further claimed their anti-war criticism would politicize the Bull Durham event. Yet he, himself, had been politicizing the Hall for several years. A longtime Republican Party operative, including Reagan White House Assistant Press Secretary, Petroskey was intimate with the Bush family. He gave George Bush a lifetime Hall pass, nominated him for Hall induction, and installed a special baseball exhibit in the White House. Every new Hall employee was required to watch a video of a Bush political speech, and only a year earlier Petroskey hosted Bush White House press secretary Ari Fleischer at the Hall, to talk, not about baseball, but about Republican politics and the war on terrorism.

\section{Responding to Petroskey, Tim Robbins wrote:}

I was unaware that baseball was a Republican sport. You invoke patriotism and use words like 'freedom' to intimidate and bully. In doing so, you dishonor the words and the men and women who have fought wars to keep this nation a place where one can freely express their opinions without fear of reprisal.

Petroskey's Bull Durham cancellation generated thousands of protests. Prominent baseball writer Roger Kahn withdrew his collected papers from the Hall, indicating 
that: "By canceling the Bull Durham [celebration] for political reasons, you are, far from supporting our troops, defying the noblest of the American spirit." Prominent journalist Mitch Albom asked:

Where do you begin with such misguided patriotism? It's the Baseball Hall of Fame, not the Pentagon. Who decided [the Hall's] position on the Middle East? A couple of Hollywood types do not put bullets in our troops. Half the world already spoke out against the war. Hugging the flag is simple. Hugging what it stands for is harder.

Sportswriter Gwen Knapp used her critique of Petroskey to challenge baseball's broader militarism, including the ear-shattering Air Force flyovers at ball games since 9/11:

the ritual is fundamentally disrespectful to military operations. [Having] those planes at a sporting event trivializes their real purpose. Baseball pretends to be honoring the military [but] it's really aggrandizing itself, a commercial entity exploitatively wrapped in red, white, and blue. It's patriotism as a marketing tool.

Even so, Petroskey stuck to his decision to cancel the Bull Durham celebration. And while he was happy to run an exhibit on baseball and the US-Afghan War, Petroskey also shelved the Hall of Fame's Latin American Baseball Project because its main sponsor was the Citgo Petroleum Corporation. Owned by Venezuela, Petroskey was protesting that nation's leader, Hugo Chavez, and his recent foreign policy clashes with the Bush administration, which had attempted to topple the Chavez government.

\section{God Bless America}

The Iraq War stirred another controversy in baseball, as well. While MLB's backing of U.S. military policies had already been overwhelming, Commissioner Selig nevertheless decided the mandatory Star Spangled Banner at all ballgames wasn't sufficient nationalistic fervor after 9/11. So he decreed that "God Bless America" also be sung at each game's seventh inning stretch as a military tribute.

Professional ballplayers were reluctant to challenge this, and the one visible ballplayer exception only underscored the norm of baseball's support for U.S. militarism. That dissenter was Carlos Delgado who, while playing for the Toronto Blue Jays, remained in the dugout during the playing of "God Bless America." Seen here, juxtaposed with U.S. soldiers in Iraq, Delgado opposed the song because it was being used to justify American military intervention in Iraq: "It's a very terrible thing that happened on September 11. But it's also a terrible thing that's happening in Afghanistan and Iraq. I think it's the stupidest war ever."

While the Blue Jays tolerated Delgado's dissent, he got a much different reception when he went to play in New York in July 2004. At Yankee Stadium, "God Bless America" was not optional for fans. Under orders from owner George Steinbrenner, ushers strung up chains during each seventh inning stretch to keep people standing and blocked from leaving for the bathroom or concessions until "God Bless America" was finished playing. While most people acquiesced, there's a court case pending by one fan who sued the Yankees for blocking his way, roughing him up, ejecting him, and having him arrested when he sought to leave his seat during the song.

In any case, during each of Carlos Delgado's at bats, he was greeted in New York with boos and then derisive shouts during each game's seventh inning stretch. When he made an out, chants of "USA! USA!" went up in the crowd. Labeled "un-American" and 
unfit to collect his paycheck, some claimed Delgado's protest "made him a terrorist who should be jailed."

In 2006, when Delgado was signed by the New York Mets, he was required to stand for "God Bless America," and he finally relented. Delgado's silencing illustrated a larger problem. According to William Arkin:

an attitude [developed] during the Iraq war that the team-the U.S. military-can't be criticized. There is no room to call someone to task for his managing, fielding or batting errors, no matter how egregious, and to actually hold the team itself accountable is to be disloyal to the big team, the country.

Even so, a few others questioned "God Bless America" as well. Historian Howard Zinn wondered why we would expect that God would single out one nation, with only $5 \%$ of the world's population, for his or her blessing? Others were puzzled why "God Bless America" was imposed in Canada, at Toronto and Montreal games, with the expectation that Canadians would sing it. And what about the 30 percent of all major leaguers and the many fans who were not Americans? Sports broadcaster Bill Littlefield worried that since politicians were "considering yet another military target [Iran], baseball would have to come up with another patriotic song and another place to put it: perhaps 'Yankee Doodle Dandy' after the top of the third inning."

Complementing the patriotic songs, Commissioner Selig also mandated American flags on all major league caps, helmets, and jerseys, as well as on the bases after 9/11. Even the Canadian teams were required to wear American flag patches. As Paul Lukas suggested: "It was hard not to imagine Canadian fans feeling just a little bit resentful, a point worth considering since resentment over American nationalism is part of what inspired the World Trade Center attack in the first place."

Additional dissent emerged in a cartoon, which used baseball to make a connection between steroids and U.S. foreign policy in Iraq. It showed the infamous Halliburton Corporation as a bulked up ballplayer who's being injected with a syringe that reads: "No-bid government contracts," in reference to the profiteering that company engaged in, with lucrative military contracts, first for helping destroy Baghdad, and then for helping to rebuild it. The cartoon was viewed as so controversial it was blocked from publication by the Mobile Register and other newspapers.

\section{Pledge Your Allegiance}

80 In the nation's capital, the Montreal Expos franchise arrived in 2005 and was reborn as the Washington Nationals. Using the motto, "Pledge Your Allegiance," the team wasted no time bonding with the D.C. military community. The team quickly hosted a Military Appreciation Night featuring "Operation Tribute to Freedom," where 10 new U.S. Army recruits were sworn in, with President George W. Bush and Secretary of State Condoleezza Rice both sharing the spotlight. Then it became the first baseball franchise to promote "America Supports You," a Pentagon program "to give visibility to citizens [who] show their appreciation to America's Armed Forces," which was launched at the July 4th game, where fans watched a Defense Department video featuring Nationals ballplayers plugging the program. Since then, there's been an almost unceasing tribute paid by the Nationals to the U.S. military.

81 While few other teams could fully match the Nationals, every other ball club paid similar devotion to the military and the wars. In San Diego, for example, the Padres 
admitted military personnel to the ballpark for free and divided each section by military branch. Also, for each Sunday home game, "the Padres celebrate and give respect for our fighting troops by proudly wearing [military] camouflage uniforms, where GI Joe meets Abner Doubleday," thus helping perpetuate-by the way-baseball's founding myth into the twenty-first century. Not to be outdone, the Chicago White Sox also donned their own version of camouflage uniforms.

\section{Strikeouts for Troops}

In San Francisco, the Giants promoted armed forces events such as its Military Sundays. One of its main television sponsors was the U.S. Marine Corps, which solicited enlistments, underwrote the U.S. Marines "Leaders of the Game," and sponsored the "Honor Roll Defensive Play of the Game." Giants pitcher Barry Zito founded "Strikeouts for Troops" in 2005, which enlisted pitchers to contribute for each strikeout and later batters for each home run. With organized baseball's endorsement, the funds assisted troops wounded in Iraq and Afghanistan recovering at U.S. military hospitals. Zito indicated that: "Baseball is ingrained in the fabric of America, just like the military. We thought it was a good marriage."

A worthy cause without question, yet Zito also claimed that: "More than anything, it's not about a partisan agenda, it's not about supporting the war or not." Yet the funds raised by "Strikeouts for Troops" were all given for distribution to the Freedom Alliance, a right-wing, pro-war organization featuring the conservative broadcaster Sean Hannity and Alliance founder Oliver North. The group's annual Defender of Freedom Award has gone exclusively to right-wing politicos, its board is filled entirely with Republicans and religious fundamentalists, and their biggest endorsement came from pro-war presidential candidate, John McCain.

For promoting programs like this and other patriotic displays, Commissioner Bud Selig was awarded the USO Gold Medal in December 2006, which goes to the person providing the greatest support for the U.S. military. Accepting the award, Selig observed that: "There has been a long and proud relationship between baseball and the U.S. military since the Civil War."

\section{Changing the Guard}

As President Bush's second term wound down, he set new records for low popularity ratings for a U.S. president. Among other things, his wars on terrorism, Afghanistan and Iraq were not going well. And in March 2008, even the fans of the normally superpatriotic Washington Nationals booed the President as he threw out the first pitch of the game-perhaps the ultimate indication the President had lost credibility with the American people. But what would come next?

A lot of people had high hopes for a new rookie, who proudly championed his hometown Chicago White Sox. Optimists that President Barak Obama can bail the nation out of its troubles, both at home and abroad. Some are a little concerned, however, about some of his foreign policy initiatives. He's promised to leave Iraq, but he's significantly escalated U.S. military involvement in Afghanistan. He's talked peace in the Middle East, yet done little to dismantle America's war on terrorism. He's tried to 
reduce tensions with the baseball fanatic and Venezuelan President, Hugo Chavez, yet U.S. policies toward Cuba remain unchanged and the White House has proposed an escalation of the drug wars in Colombia. In the end, will obama be a disappointment, or will he emerge as the Jackie Robinson of American politics-defusing the 'roid rage of U.S. foreign and military policies?

\section{The Mighty Casey Strikes Out?} apparent purpose. In response to the government's belated badgering of baseball, the Atlantic Monthly advised Bud Selig to provide his own analysis of performanceenhancing drugs, along the lines of this "Letter from the Commissioner:"

Dear U.S. Government:

When key players in the Bush administration appeared in 2005 before [MLB] and declared under oath they had never knowingly used steroids while conducting foreign policy, they were not being truthful. Formerly classified urine samples confirm that Donald Rumsfeld and Paul Wolfowitz regularly injected each other in the buttocks with anabolic steroids during the 2001 and 2002 seasons. While critics noted the two men's freakish increase in head size and sense of invincibility, we were slow to recognize the problem, despite the administration's dramatic surge in home runs and invasions in far-off lands.

As early as fall 2001, after the American military's success in crushing both the Taliban and the single-season home run record, insiders began to worry that Mr. Bush and Mr. Cheney were becoming prone to the spasmodic aggressiveness common among steroid abusers. While Mr. Bush used such six-shooter phrases as 'You're either with us or agin' us,' Mr. Cheney muscled the country into war with Iraq by making nonexistent links between al-Qaeda and Saddam Hussein. Then, during a hunting outing, Mr. Cheney flew into a full-blown 'roid rage and sprayed his partner in the face with birdshot.

Thus, retroactive to the 2001 season, every international initiative and batting statistic generated by the Bush administration shall be accompanied in the official Major League history books by an asterisk, and the 2001 to 2007 seasons will henceforth be known as the Steroid Era of American foreign policy.

Bud Selig, Commissioner of Baseball 


\section{A New Dose of Flag Waving Patriotism?}

Baseball signed on early to America's imperial ambitions, partly because it had similar aspirations. For most of our history, the sport has been drafted by the nation's empire builders, and baseball has eagerly enlisted. As the U.S. has projected its dominance worldwide, baseball has lent a hand-bolstering the U.S. military, boosting the nation's global economic reach, and proselytizing for the American way. As the U.S. expanded, conquering new frontiers, so too did baseball. Each found multiple uses for each other. And for the most part, all seemed well.

Yet New York Times foreign correspondent Stephen Kinzer worried about the future:

A seemingly invulnerable power that overreaches and suddenly suffers defeats that expose its weakness and threaten its hegemony-that is the story of the U.S. as this fifth summer of [the Iraq] war begins. It is also the story of America's most successful sports team, the New York Yankees. What is happening to them is also happening to President Bush, the Republican Party, and the U.S. itself. Each swaggered into the twenty first-century with a triumphal air, rich and secure, looking forward to [long-term] dominance. [O]verconfidence lulled them in to a false sense of security. Now they are facing undreamed-of troubles. Both need to set a different course or risk seeing their power slip away.

Organized baseball has benefited from its special status in America but its alliance with America's foreign policy establishment has produced a "national pastime tradeoff," that has jeopardized the sport's integrity and independence. While we'd hardly expect it to be purposely unpatriotic, baseball has instead gone to the opposite extreme, adopting an often militaristic and jingoistic nationalism that sometimes makes baseball into merely an extension of the government or the Armed Forces. This blind patriotism has linked baseball with policies that have put the game in a bad light, where it no longer seems to be reflecting the best of American values.

At the moment, performance-enhancing drugs might seem like baseball's greatest challenge. Yet MLB's reaction to America's performance-enhanced foreign policies may matter as well. There are limits to how a sport can shape a nation, but even so: what kind of society does baseball really want to reflect? Should baseball pursue a new dose of flag-waving patriotism to fight off football's challenge? Or should the sport rejuvenate its role as the national pastime by letting football beat the war drums, while baseball instead pushes the nation to live up to its ideals? These are questions worth considering.

\section{BIBLIOGRAPHIE}

Extensive documentation for this essay can be found at: https://docs.google.com/document/d/ 1EtRv5w9ot60h3rxz1jOLmq6-mK4lgpkL7JF6fTHDm9k/edit?hl=en\&authkey=CL7KmF0 


\section{NOTES}

1. Yet ironically, he had been using other performance-enhancing drugs for many years: Palmeiro was the major "pitch man" for Viagra commercials, such as the ads indicating that, "For Rafael Palmeiro and so many other guys, VIAGRA is a home run." But there's an even further irony here since recently it's been revealed that Viagra and other sexual enhancement drugs improve athletic performance and are being used by baseball players and other athletes for that purpose. How do we ban Viagra from the locker room?

\section{AUTEUR}

ROBERT ELIAS

University of San Francisco 